\title{
PHENOTYPIC AND MORPHOMETRIC CHARACTERIZATION OF INDIGENOUS CHICKENS AT JHENAIGATI UPAZILA OF SHERPUR DISTRICT IN BANGLADESH
}

\author{
F. Tabassum*, M. A. Hoque, F. Islam, C. H. Ritchil, M. O. Faruque \\ and A. K. F. H. Bhuiyan
}

Department of Animal Breeding and Genetics, Bangladesh Agricultural University, Mymensingh 2202

\begin{abstract}
The study was conducted at Rangtia, Shalchura and Dudhnoi villages under Jhenigati upazilla of Sherpur district in Bangladesh for phenotypic and morphometric characterization of indigenous chickens. Among three types of indigenous chickens, Non-descript Deshi were prominent (86\%), compared to Cap Headed (10\%) and Naked Neck (4\%) and the overall mean body weight, back length, body circumference and pelvis width were $961.50 \pm 17.79 \mathrm{gm}, 152.70 \pm 1.29 \mathrm{~mm}, 219.20 \pm 1.89 \mathrm{~mm}$ and $25.57 \pm .62 \mathrm{~mm}$ respectively. The prominent colors of plumage, shank, skin, earlobe and eggshell were multiple (24\%), white (52\%), white $(89 \%)$, white \& red (47\%) and white (48\%), respectively while $99 \%$ chicken's had single comb. The highest correlation (0.70) was observed between body weight $\&$ body circumference followed by $(0.36)$ between body weight \& back length and $(0.27)$ between body weight \& pelvis width while eggshell color was significantly correlated with body weight $(-0.48)$, body circumference $(-0.41)$ and pelvis width $(-0.26)$. However, comb type was significantly $(p<0.05)$ affected body weight and pelvis width. But bird type had significant $(p<0.05)$ effect on pelvis width only. Present study reveals that variations in some phenotypic characteristics have significant influence on the pelvis width and body weight while a little change in some morphometric traits may affect body weight of indigenous chickens in Bangladesh which may serve as important indicator trait(s) for future research on the conservation and development of indigenous chicken ecotypes in- situ.
\end{abstract}

Keywords: Indigenous chicken, Body measurement, Correlation, Conservation.

* Corresponding author email: mouly_198@yahoo.com

Received: 08.07.2014 


\section{INTRODUCTION}

Bangladesh Economic Review (2009) showed the highest growth rate of livestock sub-sector in GDP at constant rates (base year 1995-'96) in the years 2004-'05 (7.23\%) and 2005-'06 (6.15\%) compared to crops, vegetables $(0.15 \%)$ and fisheries (3.91\%) (MOFL, 2009). According to BBS (2010), the number of chickens and ducks were 228.04 million and 42.68 million, respectively but the national share of commercial and family poultry in terms of egg production is probably almost equal and that of meat production is 60:40 (Bhuiyan, 2011). Identification and characterization of the chicken genetic resources generally requires information on their population, adaptation to a specific environment, possession of traits of current or future value and socio cultural importance (Weigend and Romanov, 2001). Indigenous Guangua and Mecha chicken are crest/cap and plain headed, pea combed, have no shank feather (Halima, 2007). Shahjahan et al. (2011) in Bangladesh reported that traditionally local chicken perform a variety of functions, e.g. laying eggs, hatching chicks, brooding and caring of them. However, chicken types (full feathered, naked neck and cap headed indigenous chickens) have no significant effect $(P>0.05)$ on eggs per clutch (Shahjahan, 2010). High demand of indigenous (Deshi) cockerel for their tenderness and special taste was observed (Ahmed and Ali, 2007) and indigenous chickens were popular to rural, peri-urban and urban people (Chowdhury, 2012). There are a number of breeds/types of indigenous chickens such as: Non-descript Deshi, Aseel, Naked Neck, Hilly and Dwarf in Bangladesh and these are undergoing genetic erosion due to continuous indiscriminate crossing with exotic stock but no attempts have been made to improve and conserve these valued genetic resources (Bhuiyan et al., 2005). For this perspective, characterization of indigenous chicken both phenotypically \& morphometrically is important. However, objectively taken data pertaining to phenotypic \& morphometric characteristics of Indigenous chicken in-situ are limited in Bangladesh. So, this study was designed to evaluate the phenotypic and morphometric traits of indigenous chickens and to reveal the relationship among them.

\section{MATERIALS AND METHODS}

\section{Location of study area}

Data were collected from the villages named, Rangtia $\left(25^{\circ} 22^{\prime} \mathrm{N} \& 90^{\circ} 09^{\prime} \mathrm{E}\right)$, Shalchura $\left(25^{\circ} 21^{\prime} \mathrm{N} \& 90^{\circ} 08^{\prime} \mathrm{E}\right)$ and Dudhnoi $\left(25^{\circ} 18^{\prime} \mathrm{N} \& 90^{\circ} 09^{\prime} \mathrm{E}\right)$ of Jhenaigati upazila under Sherpur district in Bangladesh.

\section{Data collection}

An elaborate household survey (called In-depth Household Survey) was conducted at April 2011 and August 2011 on 59 randomly selected households at Jhenaigati upazila of Sherpur district in Bangladesh under the UNEP-GEF-ILRI FAnGR Asia Project. The birds reared in these households were wing banded and in-depth survey data were collected on bird and comb type, plumage, shank, skin, earlobe and egg 
shell color, body weight, back length, body circumference and pelvis width. Individual birds were measured and to have the live body weight a $5 \mathrm{~kg}$ weighing balance (CAMRY, CHINA.) was used while different body organs were measured following the instruction narrated in figure 1 using a $150 \mathrm{~cm}$ plastic tailoring tape (Butterfly Brand, Shanghai, China).

\section{Experimental design and data analysis}

The statistical design of the study was unbalanced factorial in nature because the numbers of observations in different traits were unequal. Analyses were performed by analysis of variance (ANOVA) method using the General Linear Model (GLM) procedure under Statistical Package for the Social Sciences (SPSS 1998) version 11.5 with the option uni-variate. In addition, for significant variables, pair wise comparisons of treatment means were made using Duncan's Multiple Range Test (DMRT).

\section{RESULTS AND DISCUSSION}

\section{Phenotypic characteristics and morphometric measurements}

Non-descript Deshi were prominent (86\%), compared to Cap Headed (10\%) and Naked Neck (4\%) among three types of indigenous chickens at Jhenigati upazilla of Sherpur district in Bangladesh (Table 1) while in Ethiopia, Duguma (2006) documented three ecotypes of chicken namely Horro, Tepi and Jarso. Comb size is associated with gonadal development and intensity of light but comb type is the consequence of gene interaction (Bell, 2002). However, at present study high proportion of $(99 \%)$ single comb and lower proportion of $(1 \%)$ pea comb were found (Table 1) and similarly reported by Bhuiyan et al. (2005) in Bangladesh (97\% single comb), Apuno et al. (2011) in Nigeria (96.45\% single comb and $0.44 \%$ pea comb) and Badubi et al. (2006) in Botswana (90\% single comb and $1 \%$ pea comb).Thus the results of the present study and published reports from others research works suggested that the single comb is dominant over any comb type. We observed variation in plumage colors of indigenous chickens in Bangladesh, where multiple plumage color (24\%) was prominent followed by others, black, black \& white, red brown, red, white, yellow, grayish and white \& red (table 1) and this finding was in line of the research work of Melesse and Negesse (2011) in indigenous chickens in southern region of Ethiopia (Kei, Tikur, Gebsima, Netch, Kokima, Wosera, Zagolima and Zigrima) and Daikwo et al. (2011) in chicken of Dekina (Brown/Black 35.5\%, Black $10.25 \%$, Black/White $6.5 \%$, Brown/Black/White $3.25 \%$, \& White $2.75 \%$ ). However these birds possessed shanks with different colors (Table 1) like white $(52 \%)$, black (36\%), yellow (10\%) and white with red (2\%) and among these, white color was prominent to others and this finding was supported by Faruque et al. (2010) in Bangladesh. Similarly, Youssao et al. (2010) reported the most predominant shank colors were white in forest ecotypes than that of Savannah though there were birds with grey, black \& yellow colored shanks but dissimilarly Daikwo et al. (2011) found 
yellow colored shanks dominant over black/yellow, black and white in chickens of Dekina. Complete absences of black pigments in dermis and yellow pigments in epidermis of shanks, results the colors are white (Bell, 2002). White (89\%) skin colored birds were prominent over yellow skin in indigenous chickens of Bangladesh (table 1) and this finding was supported by Bhuiyan et al. (2005) in Bangladesh and Dana et al. (2010) in Ethiopia. Most of the birds had white with red earlobe color $(47 \%)$ but there were birds with black (32\%), red (16\%), others $(3 \%)$ and red brown $(2 \%)$ colored earlobe in indigenous chickens (Table 1) while Biswas (2005) observed the red earlobe color (58\%) was prominent over white $(45.8 \%)$ but Ahmed and Ali (2007) found $80.55 \%$ white earlobe color of Deshi chicken. Indigenous chickens laid mainly eggs with (48\%) white shell and (20\%) red brown shell (Table 1) while Bhuiyan et al. (2005) documented light brown (67\%) and white (27\%) shelled eggs of the indigenous chickens in Bangladesh. However, Biswas (2005) reported that the hens of Non-descript Deshi, Hilly and Naked Neck laid light brown (62.42\%) to cream or off white $(30.28 \%)$ colored eggs. The highest mean body weights were (table 5.1) observed in Cap Headed bird $(972 \pm 37.02 \mathrm{gm})$ followed by Non-descript Deshi $(966.4 \pm 19.73 \mathrm{gm})$ and Naked Neck $(830 \pm 86.6 \mathrm{gm})$ and mean body weight of over all indigenous chickens under study was $961.50 \pm 17.79 \mathrm{gm}$ and which was very close to the findings of Islam et al. (2012) but lower than Semakula et al. (2011), Ssewannyana et al. (2003) and Kyarisiima et al. (2004). Mean back length (table 5.1), body circumference and pelvis width of over all indigenous chickens under study were $152.70 \pm 1.29,219.20 \pm 1.89$ and $25.57 \pm 0.62 \mathrm{~mm}$ respectively in indigenous chickens of Bangladesh while Semakula et al. (2011) found back length and chest circumference of male birds (215 and $292.3 \mathrm{~mm}$ respectively) higher than female birds (194 and 257mm respectively) at the age of 10 months and above.

\section{Correlation among phenotypic traits}

Bird and comb type, shank, eggshell, earlobe, skin and plumage color had no significant correlation between each other. So bird type, plumage color, shank color or eggshell color did not affect each other significantly (Table 2). However, Guni et al. (2013) reported that plumage color was closely associated with shank and earlobe color, shank color was associated with skin and earlobe color while, earlobe color was associated with comb type in Tanzanian chicken.

\section{Correlation among morphometric traits}

The highest correlation (0.70) between body weight \& body circumference followed by correlation (0.36) between body weight \& back length and correlation (0.27) between body weight \& pelvis width were observed but there were no significant correlation between back length \& body circumference, back length \& pelvis width and body circumference \& pelvis width (Table 3). However Gueye et al. (1998) reported that, the correlations between body length and live weight $(\mathrm{r}=0.33)$ was positive and significant $(\mathrm{p}<0.01)$ in Senegalese chicken but according to Alabi et al. (2012) body weight was highly correlated with linear body measurements in Naked 
Neck and Venda chickens and it was non-significant ( $p>0.01)$ in Koekoek chicken of South Africa. Apuno et al. (2011) also found significant correlation between body weight, back length and body circumference in Nigerian indigenous chicken. On the other hand Faruque et al. (2007) reported high degree of correlation between body weight and linear body measurements and they observed the best correlation in Naked Neck chicken while Daikwo et al. (2011) found body weight of chicken in Dekina highly correlated with back length and body circumference. So, results of the present study and findings of other scientists suggested that selection for any of these linear body measurements will cause direct improvement in body weight.

\section{Correlation among morphometric \& phenotypic characters}

There was no significant correlation between phenotypic traits and morphometric traits except correlation of eggshell color with body weight, body circumference and pelvis width (Table 4). However, eggshell color was significantly correlated with body weight (-0.48), body circumference $(-0.41)$ and pelvis width $(-0.26)$ and this study is suggesting the possibility in the reduction of specific eggshell color with the increase of body weight, body circumference and pelvis width. On the contrary, Buvanendran and Merritt (2011) observed a consistent trend towards a darker egg shell color with increasing body weight in meat type chicken.

\section{Effects of phenotype on morphometric traits}

Bird type had significant $(\mathrm{p}<0.05)$ effect on pelvis width (table 5.1) while there was no significant effect of plumage (Table 5.2) shank, skin (table 5.3), earlobe and eggshell (table 5.4) color on body weight, back length, body circumference and pelvis width. While Faruque et al. (2010) reported significant differences of body weight among Indigenous Naked Neck, Hilly \& Non-descript Deshi chicken. However, comb type significantly $(\mathrm{p}<0.05)$ affected body weight and pelvis width (table 5.1)

\section{Effect of bird type}

Bird types had no significant effect on body weight and back length and similar findings were reported by Faruque et al. (2007) but Alabi et al. (2012) found significant effect in South Africa. Bird type also had no effect on body circumference and similar observation was reported by Youssao et al. (2010) in Benin between two ecotypes namely Savannah \& Forest while bird types had the significant effect on pelvis width in indigenous chickens of Bangladesh. On the other hand bird types (full feathered, naked neck and cap headed indigenous chicken) had no significant effect (p>0.05) on eggs per clutch (Shahjahan, 2010). However, among three types of indigenous chickens in present study, Naked Neck had comparatively lower body weight, back length, body circumference and pelvis width than Non-descript Deshi and Cap headed chicken and this findings was in line with the research work of Sarker et al. (2014). 


\section{Effect of comb type}

Comb type had no significant effect on back length and body circumference but body weight and pelvis width of indigenous chickens in Bangladesh were significantly affected but Apuno et al. (2011) found no significant ( $>0.05 \%)$ effect in Senegalese chicken. However, Comb size of dam had non significant influence on day old chick weight, 6th week chick weight and 11th week chick weight (Haq et al., 2003).

\section{Effect of plumage color}

Plumage colors did not affect body weight, back length, body circumference and pelvis width significantly but Sarker et al. (2014) found significant effect of plumage color on body weight of Indigenous chicken in Bangladesh. On the other hand, Apuno et al. (2011) found significant effect of plumage colors on back length and body circumference in Senegalese chicken. However, Shahjahan et al. (2011) found significant effect of specific plumage colors and age groups $(\mathrm{p}<0.05$ and $\mathrm{p}<0.01$, respectively) on egg production.

\section{Effect of shank color}

Shank colors had no significant effect on body weight, back length, body circumference and pelvis width similarly, Apuno et al. (2011) found no significant effect on body weight and back length in Senegalese chickens.

\section{Effect of skin, earlobe and eggshell color}

Skin, earlobe and eggshell colors had no significant effect on body weight, back length, body circumference and pelvis width. However, Older hens lay lighter colored eggs (Odabasi et al., 2007) and in respect to medium and heavy birds, light broilers produced breast meat with higher values of redness (Bianchi et al., 2007).

\section{CONCLUSION}

Present study reveals that variations in some phenotypic characteristics had significant influence on the pelvis width and body weight while selection for some linear body measurements will cause direct improvement in body weight of Indigenous chickens in Bangladesh. The results of this work may therefore serve as an important base for future research on the conservation and development of Indigenous chicken ecotypes in- situ.

\section{ACKNOWLEDGEMENT}

Authors are thankful to the UNEP-GEF-ILRI-FAnGR Asia Project for having the opportunity to use the data for this study. 


\section{REFERENCES}

Ahmed, S.T. and Ali, M.A. 2007. Performance of Synthetic, Desi, Synthetic x Desi and Synthetic x Star cross brown chicken at marketing. Proceedings of the $5^{\text {th }}$ International Poultry Show and Seminar. Organized by World's Poultry Science Association, Bangladesh Branch. 01-03 March, 2007, pp. 18-25

Alabi, O. J., Norris, D. and Egena, S. S. A. 2012. Comparative Study of Three Indigenous Breeds of South Africa: Body Weight \& Linear Body Measurements. Agricultural Journal, 3: 220-225

Apuno, A. A., Mbap, S.T. and Ibrahim, T. 2011. Characterization of local chickens (Gallus gallus domesticus) in Shelleng and Song Local Government Areas of Adamawa State, Nigeria. Agriculture and Biology Journal of North America, 2(1): 6-14.

Badubi, S.S., Rakereng, M. and Marumo, M. 2006. Morphological characteristics and feed resources available for Indigenous chickens in Botswana. Livestock Research for Rural Development, 18(1)

Bianchi, M., Petracci, M., Sirri. F., Folegatti, E., Franchini, A. and Meluzzi, A. 2007. The influence of the season and market class of broiler chickens on breast meat quality traits. Poultry Scince, 86(5):959-63

Biswas, S.R. 2005. Genetic Dilution of of Indigenous Chicken in Selected Villages. MS Thesis. Department of Animal Breeding and Genetics, Bangladesh Agricultural University, Mymensingh

BBS, 2010. Bangladesh Bureau of Statistics, Statistics Division, Ministry of Planning, Government of the Peoples Republic of Bangladesh, Dhaka

Bell, D.D. 2002. Anatomy of the chicken. In D.D. Bell and W. D. Weaver eds. Commercial chicken meat and egg production, $5^{\text {th }}$ edition. pn., pp. 45-46. USA, Springer Science + Business Media, Inc

Bhuiyan, A. K. F. H. 2011. Implementation of National Livestock Development Policy (2007) and National Poultry Development Policy (2008): Impact on smalholder livestock rearers. Keynote paper presented at the South Asia Pro Poor Livestock Policy Programme (SAPPLP)-BRAC workshop held at BRAC Centre Inn, Dhaka

Bhuiyan, A.K.F.H., Bhuiyan, M. S. A. and Deb, G.K. 2005. Indigenous chicken genetic resources in Bangladesh: Current status and future outlook. Animal Genetic Resources Information (AGRI), FAO, Italy, 36: 73-84

Buvanendran, V. and Merritt, E.S. 2011. Correlated responses in egg quality traits to selection for early body weight in meat type chicken. Canadian Journal of Genetics and Cytology, 14 (3):477-482

Chowdhury, S. D. 2012. Keynote Paper on Indigenous poultry: Need for policy intervention and sustainable approaches to higher productivity. Proceedings of a Seminar, 28 January, 2012, Animal Husbandry Faculty Gallery, Bangladesh Agricultural University, Mymensingh 2202. pp. 8-20

Dana, N., Dessie, T., van der Waaij, H.L. and van Arendonk, A.M.J. 2010. Morphological features of indigenous chicken populations of Ethiopia. Animal Genetic Resources, 46: $11-23$ 
Daikwo, I. S., Okpe, A. A. and Ocheja, J.O. 2011.Phenotypic Characterization of Local Chickens in Dekina. International Journal of Poultry Science, 10 (6):444-447

Duguma, R. 2006. Phenotypic characterization of some Indigenous chicken ecotypes of Ethiopia. Ethiopian Institute of Agricultural Research, P.O. Box 32, Debre Zeit, Ethiopia. Livestock Research for Rural Development, 18(9)

Faruque, S., Sarker, N.R., Islam, M.N. and Sarker, M.S.K. 2007. Performance of native chicken under intensive system. Journal of the Bangladesh Agricultural University, 5(2): 283-288

Faruque, S., Siddiquee, N. U., Afroz, M. A. and Islam, M. S. 2010. Phenotypic characterization of Native Chicken reared under intensive management system. Journal of the Bangladesh Agricultural University, 8(1): 79-82

Guni, F. S. and Katule, A. M. 2013. Characterization of local chickens in selected districts of the Southern Highlands of Tanzania: I. Qualitative characters. Livestock Reseaech for Rural Development, 25(9)

Gueye, E.F. Ndiaye, A. and Branckaert, R. D. S.1998. Prediction of body weight on the basis of body measurements in mature indigenous chickens in Senegal. Livestock Research for Rural Development, 10(3)

Haq, A., Akram, M., Mukhtar, N.,Rehman, S. and Ramzan, M. 2003. Effect of Parental Comb Size and Body Weight on Subsequent Performance in Lyallpur Silver Black Layers. Pakistan Journal of Life and Social Science, 1(2): 98-101

Halima, H.M. 2007. Phenotypic and genetic characterization of indigenous chicken populations in Northwest Ethiopia. Ph.D. Thesis, University of Free State, Bloemfontein, South Africa

Islam, F., Sarker, S. C., Bhuiyan, A. K. F. H., Akteruzzaman, M., Bett, R.C., Baltenweck, I., Poole, J., Ibrahim, M.N.M. and Okeyo, A. M. 2012. The status of indigenous chicken farming and options for improvement in Bangladesh. Proceedings of a Seminar, 28 January, 2012, Animal Husbandry Faculty Gallery, Bangladesh Agricultural University, Mymensingh. p. 21

Kyarisiima, C. C., Kugonza, D. R. and Twesigye, C. K. 2004. The Potential Role of Uganda Indigenous Chicken in Poverty Alleviation. The Uganda Journal, 50: 85-90.

Melesse, A. and Negesse, T. 2011. Phenotypic and morphological characterization of indigenous chicken populations in southern region of Ethiopia. Animal Genetic Resources, 49:19-31

MOF. 2009. Bangladesh Economic Review, Ministry of Finance, Government of the People's Republic of Bangladesh.

Odabasi, A.Z., Miles, R.D., Balabn, M. O. and Portier, K. M. 2007. Changes in brown eggshell color as the hen ages. Poultry Scinece, 86(2):356-63

Sarker, N. R., Hoque, A., Faruque, S.,Islam, N. and Bhuiyan, F. H. 2014. An ex situ study on body characteristics and effect of plumage color on body weight of indigenous chicken (Gallus domesticus) in Bangladesh. Animal Sciences, 36: 79-84

Semakula, J., Lusembo, P., Kugonza, D. R., Mutetikka, D., Ssennyonjo, J. and Mwesigwa, M. 2011. Estimation of live body weight using zoometrical measurements for 
improved marketing of indigenous chicken in the Lake Victoria basin of Uganda. Livestock Research for Rural Development, 23: (8)

Ssewannyana, E., Onyait, A. O., Ogwal, J., Mukasa, B., Nsamba, P and Masaba, J. 2003. Characteristics of Rural Chicken in Apac and Kumi districts of Uganda. Uganda Journal of Agricultural Sciences, 8:159-164

Shahjahan, M. 2010. Diversity in performance of Indigenous Chicken in some selected areas of Bangladesh In-Situ. A Thesis for M. S. degree, Submitted to the Department of Animal Breeding and Genetics, Bangladesh Agricultural University, Mymensingh2202

Shahjahan, M., Amin, M.R. and Bhuiyan, A.K.F.H. 2011. Diversity in performance of indigenous chicken in some selected areas of Bangladesh in-situ. Proceedings of 9 Asia Pacific Poultry Conference, the World's Poultry Science Association Taiwan Branch, 20-23 March, 2011. Taipei, Taiwan. Mon-S4-08. CD

SPSS, 1998. Statistical Package for the Social Sciences. SPSS Inc. an IBM Company Headquarters, 233 S.WAckes Drive, 11 th floor Chicago,Illinois 60606

Weigend, S. and Romanov, M.N. 2001. Current strategies for the assessment and evaluation of genetic diversity in chicken resources. World Poultry Science Journal, 57: 275-287

Youssao, I. A. K., Tobadal, P. C., Koutinhouinl, B. G., Dahouda, M., Idrissou, N. D., Bonou, G. A., Tougan, U. P., Ahounou, S., Yapi-Gnaoré, V., Kayang, Rognon, B., X. and Tixier-Boichard, M. 2010. Phenotypic Characterization and Molecular Polymorphism of Indigenous Poultry Population of the species Gallus gallus of Savannah and Forest ecotypes of Benin. African Journal of Biotechnology, 9(3): 369-381 
Table 1: Frequencies of bird and comb type, plumage, shank, comb, skin, earlobe and eggshell colors in indigenous chickens

\begin{tabular}{|c|c|c|c|c|c|c|c|}
\hline \multicolumn{2}{|c|}{ Phenotypic Parameter } & \multirow{2}{*}{$\begin{array}{c}\text { Percenta } \\
\text { ge }(\%)\end{array}$} & \multirow{4}{*}{$\begin{array}{l}\text { Total } \\
100\end{array}$} & \multicolumn{2}{|c|}{$\begin{array}{l}\text { Phenotypic } \\
\text { Parameter }\end{array}$} & \multirow{2}{*}{$\begin{array}{l}\text { Percentag } \\
\text { e }(\%)\end{array}$} & \multirow{2}{*}{$\begin{array}{l}\text { Total } \\
100\end{array}$} \\
\hline \multirow{3}{*}{$\begin{array}{l}\text { Bird } \\
\text { Type }\end{array}$} & Naked Neck & & & \multirow{2}{*}{$\begin{array}{l}\text { Comb } \\
\text { Type }\end{array}$} & Single & & \\
\hline & Non-descript Deshi & 86 & & & Pea & 1 & \\
\hline & Cap Headed & 10 & & \multirow{3}{*}{$\begin{array}{l}\text { Skin } \\
\text { Color }\end{array}$} & White & 89 & 100 \\
\hline \multirow{10}{*}{$\begin{array}{l}\text { Pluma } \\
\text { ge } \\
\text { Color }\end{array}$} & Black & 15 & \multirow[t]{10}{*}{100} & & Yellow & 9 & \\
\hline & White & 5 & & & Not Definite & 2 & \\
\hline & Yellow & 4 & & \multirow{5}{*}{$\begin{array}{l}\text { Earlo } \\
\text { be } \\
\text { Color }\end{array}$} & Black & 32 & \multirow[t]{5}{*}{100} \\
\hline & Red & 8 & & & Red & 16 & \\
\hline & Grayish & 3 & & & Red Brown & 2 & \\
\hline & Multicolor & 24 & & & $\begin{array}{l}\text { White and } \\
\text { Red }\end{array}$ & 47 & \\
\hline & Black and White & 12 & & & Others & 3 & \\
\hline & Red Brown & 10 & & \multirow{7}{*}{$\begin{array}{l}\text { Egg } \\
\text { shell } \\
\text { Color }\end{array}$} & White & 48 & \multirow[t]{7}{*}{100} \\
\hline & White and Red & 2 & & & Red & 2 & \\
\hline & Others & 17 & & & Red Brown & 20 & \\
\hline \multirow{4}{*}{$\begin{array}{l}\text { Shank } \\
\text { Color }\end{array}$} & Black & 36 & \multirow[t]{4}{*}{100} & & Others & 24 & \\
\hline & White & 52 & & & \multirow[t]{3}{*}{ Not Definite } & \multirow[t]{3}{*}{6} & \\
\hline & Yellow & 10 & & & & & \\
\hline & White and Red & 2 & & & & & \\
\hline
\end{tabular}

Table 2: Correlation among phenotypic characters

\begin{tabular}{|l|l|l|l|l|l|l|l|}
\hline Parameter & $\begin{array}{l}\text { Bird } \\
\text { Type }\end{array}$ & $\begin{array}{l}\text { Comb } \\
\text { Type }\end{array}$ & $\begin{array}{l}\text { Plumage } \\
\text { Color }\end{array}$ & $\begin{array}{l}\text { Shank } \\
\text { Color }\end{array}$ & $\begin{array}{l}\text { Skin } \\
\text { Color }\end{array}$ & $\begin{array}{l}\text { Earlobe } \\
\text { Color }\end{array}$ & $\begin{array}{l}\text { Eggshell } \\
\text { Color }\end{array}$ \\
\hline Bird Type & 1 & -0.03 & -0.00 & 0.05 & -0.04 & -0.08 & -0.13 \\
\hline Comb Type & -0.03 & 1 & 0.14 & 0.01 & -0.02 & -0.04 & 0.00 \\
\hline $\begin{array}{l}\text { Plumage } \\
\text { Color }\end{array}$ & -0.00 & 0.14 & 1 & 0.15 & 0.10 & -0.10 & 0.01 \\
\hline Shank Color & 0.05 & 0.01 & 0.15 & 1 & 0.06 & -0.04 & -0.01 \\
\hline Skin Color & -0.04 & -0.02 & 0.10 & 0.06 & 1 & -0.02 & 0.00 \\
\hline Earlobe Color & -0.08 & -0.04 & -0.10 & -0.04 & -0.02 & 1 & 0.04 \\
\hline $\begin{array}{l}\text { Eggshell } \\
\text { Color }\end{array}$ & -0.13 & 0.00 & 0.01 & -0.01 & 0.00 & 0.04 & 1 \\
\hline
\end{tabular}


Table 3: Correlation among morphometric traits

\begin{tabular}{|l|l|l|l|l|}
\hline \multicolumn{1}{|c|}{ Parameter } & \multicolumn{1}{|c|}{$\begin{array}{c}\text { Body } \\
\text { Weight } \\
(\mathbf{g m})\end{array}$} & $\begin{array}{c}\text { Back } \\
\text { Length } \\
(\mathbf{m m})\end{array}$ & $\begin{array}{c}\text { Body Circumference } \\
(\mathbf{m m})\end{array}$ & \multicolumn{1}{|c|}{$\begin{array}{c}\text { Pelvis } \\
\text { Width } \\
(\mathbf{m m})\end{array}$} \\
\hline Body Weight $(\mathrm{gm})$ & 1.00 & $0.36^{* *}$ & $0.70^{* *}$ & $0.27^{* *}$ \\
\hline Back Length $(\mathrm{mm})$ & $0.36^{* *}$ & 1.00 & 0.04 & -0.12 \\
\hline $\begin{array}{l}\text { Body Circumference } \\
\text { (mm) }\end{array}$ & $0.70^{* *}$ & 0.04 & 1.00 & 0.08 \\
\hline Pelvis Width (mm) & $0.27^{* *}$ & -0.12 & 0.08 & 1.00 \\
\hline
\end{tabular}

** Correlation is significant at $0.01 \%$ level

Table 4: Correlation among morphometric \& phenotypic characters

\begin{tabular}{|l|l|l|l|l|}
\hline \multicolumn{1}{|c|}{$\begin{array}{c}\text { Phenotypic } \\
\text { Parameter }\end{array}$} & $\begin{array}{c}\text { Body Weight } \\
(\mathbf{g m})\end{array}$ & $\begin{array}{c}\text { Back } \\
\text { Length } \\
(\mathbf{m m})\end{array}$ & $\begin{array}{c}\text { Pelvis } \\
\text { Circumference } \\
(\mathbf{m m})\end{array}$ & $\begin{array}{c}\text { Bidth(mm) } \\
\text { Wody }\end{array}$ \\
\hline Bird Type & 0.06 & -0.04 & 0.13 & -0.01 \\
\hline Comb Type & 0.01 & -0.10 & 0.11 & -0.01 \\
\hline Plumage color & -0.09 & -0.15 & 0.04 & -0.13 \\
\hline Shank color & -0.01 & 0.09 & -0.08 & -0.12 \\
\hline Skin color & -0.07 & -0.14 & -0.14 & 0.10 \\
\hline Earlobe color & -0.11 & 0.05 & -0.18 & -0.03 \\
\hline Eggshell color & $-0.48 * *$ & 0.09 & $-0.41^{* *}$ & $-0.26 * *$ \\
\hline
\end{tabular}

**Correlation is significant at $0.01 \%$ level 
Table 5.1: Effects of bird and comb type on morphometric traits

\begin{tabular}{|c|c|c|c|c|}
\hline $\begin{array}{l}\text { Phenotypic } \\
\text { Parameter }\end{array}$ & $\begin{array}{c}\text { Body Weight } \\
\text { (gm) }\end{array}$ & $\begin{array}{l}\text { Back Length } \\
\quad(\mathbf{m m})\end{array}$ & $\begin{array}{c}\text { Body } \\
\text { Circumference } \\
(\mathbf{m m})\end{array}$ & $\begin{array}{c}\text { Pelvis } \\
\text { Width(mm) }\end{array}$ \\
\hline Bird Type & NS & NS & NS & $*$ \\
\hline $\begin{array}{l}\text { Non-descript } \\
\text { Deshi }\end{array}$ & $\begin{array}{l}966.40 \pm 19.73 \\
(86)\end{array}$ & $\begin{array}{l}153.26 \pm 1.33 \\
(86)\end{array}$ & $\begin{array}{l}218.96 \pm 2.07 \\
(86)\end{array}$ & $\begin{array}{l}25.63 \pm 0.68 \\
(86)\end{array}$ \\
\hline Naked Neck & $\begin{array}{l}830.00 \pm 86.60 \\
\text { (4) }\end{array}$ & $\begin{array}{l}147.50 \quad \pm 9.46 \\
(4)\end{array}$ & $\begin{array}{l}210.00 \pm 10.8 \\
\text { (4) }\end{array}$ & $\begin{array}{l}25.00 \pm 2.89 \\
\text { (4) }\end{array}$ \\
\hline Cap Headed & $\begin{array}{l}972.00 \pm 37.02 \\
(10)\end{array}$ & $\begin{array}{l}150.00 \pm 4.94 \\
(10)\end{array}$ & $\begin{array}{l}225.00 \pm 4.78 \\
\text { (10) }\end{array}$ & $\begin{array}{l}25.25 \pm 1.68 \\
(10)\end{array}$ \\
\hline Total & $\begin{array}{l}961.50 \pm 17.8 \\
(100)\end{array}$ & $\begin{array}{l}152.70 \pm 1.29 \\
(100)\end{array}$ & $\begin{array}{l}219.20 \pm 1.89 \\
(100)\end{array}$ & $\begin{array}{l}25.57 \pm .62 \\
(100)\end{array}$ \\
\hline Comb Type & $*$ & NS & NS & $*$ \\
\hline Single & $\begin{array}{l}961.30 \pm 17.98 \\
(99)\end{array}$ & $\begin{array}{l}961.30 \pm 17.98 \\
(99)\end{array}$ & $\begin{array}{l}961.30 \pm 17.98 \\
(99)\end{array}$ & $\begin{array}{l}961.30 \pm 17.98 \\
(99)\end{array}$ \\
\hline Pea & $\begin{array}{l}980.00 \\
(1)\end{array}$ & $\begin{array}{l}980.00 \\
(1)\end{array}$ & $\begin{array}{l}980.00 \\
(1)\end{array}$ & $\begin{array}{l}980.00 \\
\text { (1) }\end{array}$ \\
\hline Total & $\begin{array}{l}961.5 \pm 17.82 \\
(100)\end{array}$ & $\begin{array}{l}961.5 \pm 17.82 \\
(100)\end{array}$ & $\begin{array}{l}961.5 \pm 17.82 \\
(100)\end{array}$ & $\begin{array}{l}961.5 \pm 17.82 \\
(100)\end{array}$ \\
\hline
\end{tabular}

* Significant at $0.05 \%$ level of probability $(\mathrm{p}<0.05), \mathrm{NS}=$ Non Significant,

Figure in the parentheses indicate the number of observation. 
Table 5.2: Effects of plumage color on morphometric traits

\begin{tabular}{|c|c|c|c|c|}
\hline $\begin{array}{l}\text { Phenotypic } \\
\text { Parameter }\end{array}$ & $\begin{array}{c}\text { Body Weight } \\
\text { (gm) }\end{array}$ & $\begin{array}{l}\text { Back Length } \\
(\mathbf{m m})\end{array}$ & $\begin{array}{c}\text { Body } \\
\text { Circumference } \\
(\mathbf{m m})\end{array}$ & $\begin{array}{c}\text { Pelvis } \\
\text { Width(mm) }\end{array}$ \\
\hline Plumage Color & NS & NS & NS & NS \\
\hline Black & $\begin{array}{l}965.33 \pm 40.50 \\
(15)\end{array}$ & $\begin{array}{l}152.00 \pm 2.96 \\
(15)\end{array}$ & $\begin{array}{l}218.00 \pm 5.27 \\
(15)\end{array}$ & $\begin{array}{l}27.33 \pm 1.28 \\
(15)\end{array}$ \\
\hline White & $\begin{array}{l}932.00 \pm 134.85 \\
\text { (5) }\end{array}$ & $\begin{array}{l}160.00 \pm 10.00 \\
(5)\end{array}$ & $\begin{array}{l}216.00 \pm 12.88 \\
\text { (5) }\end{array}$ & $\begin{array}{l}23.50 \pm 2.69 \\
(5)\end{array}$ \\
\hline Yellow & $\begin{array}{l}952.50 \pm 54.98 \\
\text { (4) }\end{array}$ & $\begin{array}{l}152.50 \pm 6.29 \\
\text { (4) }\end{array}$ & $\begin{array}{l}210.00 \pm 4.08 \\
\text { (4) }\end{array}$ & $\begin{array}{l}27.51 \pm 4.78 \\
\text { (4) }\end{array}$ \\
\hline Red & $\begin{array}{l}1062.50 \pm 69.94 \\
(8)\end{array}$ & $\begin{array}{l}160.00 \pm 3.78 \\
(8)\end{array}$ & $\begin{array}{l}221.25 \pm 6.39 \\
\text { (8) }\end{array}$ & $\begin{array}{l}28.75 \pm 2.45 \\
(8)\end{array}$ \\
\hline Grayish & $\begin{array}{l}1026.67 \pm 63.60 \\
\text { (3) }\end{array}$ & $\begin{array}{l}153.33 \pm 12.012 \\
(3)\end{array}$ & $\begin{array}{l}223.33 \pm 6.67 \\
\text { (3) }\end{array}$ & $\begin{array}{l}21.67 \pm 1.67 \\
\text { (3) }\end{array}$ \\
\hline Multiple color & $\begin{array}{l}970.42 \pm 34.16 \\
(24)\end{array}$ & $\begin{array}{l}155.2 \pm 3.03 \\
(24)\end{array}$ & $\begin{array}{l}222.08 \pm 3.71 \\
(24)\end{array}$ & $\begin{array}{l}23.33 \pm 1.23 \\
(24)\end{array}$ \\
\hline Black \& White & $\begin{array}{l}950.83 \pm 43.61 \\
(12)\end{array}$ & $\begin{array}{l}152.50 \pm 2.17 \\
(12)\end{array}$ & $\begin{array}{l}210.83 \pm 4.34 \\
\text { (12) }\end{array}$ & $\begin{array}{l}29.59 \pm 1.79 \\
(12)\end{array}$ \\
\hline Red Brown & $\begin{array}{l}981.00 \pm 57.22 \\
(10)\end{array}$ & $\begin{array}{l}144.50 \quad \pm 2.17 \\
(10)\end{array}$ & $\begin{array}{l}230.00 \pm 6.32 \\
(10)\end{array}$ & $\begin{array}{l}26.50 \pm 1.67 \\
(10)\end{array}$ \\
\hline White \& Red & $\begin{array}{l}750.00 \pm 170.00 \\
(2)\end{array}$ & $\begin{array}{l}160.00 \\
(2) \\
\end{array}$ & $\begin{array}{l}205.00 \pm 25.00 \\
(2)\end{array}$ & $\begin{array}{l}17.50 \pm 2.50 \\
(2)\end{array}$ \\
\hline Others & $\begin{array}{l}918.23 \pm 47.29 \\
(17)\end{array}$ & $\begin{array}{l}148.23 \pm 2.90 \\
(17)\end{array}$ & $\begin{array}{l}218.82 \pm 4.44 \\
(17)\end{array}$ & $\begin{array}{l}24.11 \pm 1.23 \\
(17)\end{array}$ \\
\hline Total & $\begin{array}{l}961.50 \pm 17.80 \\
(100)\end{array}$ & $\begin{array}{l}152.70 \pm 1.30 \\
(100)\end{array}$ & $\begin{array}{l}219.20 \pm 1.89 \\
(100)\end{array}$ & $\begin{array}{l}25.57 \pm 0.62 \\
(100)\end{array}$ \\
\hline
\end{tabular}

NS=Non Significant, Figure in the parentheses indicate the number of observation. 
Table 5.3: Effects of shank and skin color on morphometric traits

\begin{tabular}{|c|c|c|c|c|}
\hline $\begin{array}{l}\text { Phenotypic } \\
\text { Parameter }\end{array}$ & $\begin{array}{l}\text { Body Weight } \\
\text { (gm) }\end{array}$ & $\begin{array}{l}\text { Back Length } \\
\quad(\mathbf{m m})\end{array}$ & $\begin{array}{c}\text { Body } \\
\text { Circumference } \\
(\mathbf{m m})\end{array}$ & $\begin{array}{c}\text { Pelvis } \\
\text { Width(mm) }\end{array}$ \\
\hline Shank Color & NS & NS & NS & NS \\
\hline Black & $\begin{array}{l}948.33 \pm 31.33 \\
(36)\end{array}$ & $\begin{array}{l}151.67 \pm 1.67 \\
(36)\end{array}$ & $\begin{array}{l}220.28 \pm 3.68 \\
(36)\end{array}$ & $\begin{array}{l}25.28 \pm 0.87 \\
(36)\end{array}$ \\
\hline White & $\begin{array}{l}974.23 \pm 25.30 \\
(52)\end{array}$ & $\begin{array}{l}153.07 \pm 1.90 \\
(52)\end{array}$ & $\begin{array}{l}220.57 \pm 2.41 \\
(52)\end{array}$ & $\begin{array}{l}26.34 \pm 0.95 \\
(52)\end{array}$ \\
\hline Yellow & $\begin{array}{l}949.00 \pm 44.63 \\
(10)\end{array}$ & $\begin{array}{l}153.00 \pm 5.78 \\
(10)\end{array}$ & $\begin{array}{l}209.00 \pm 4.06 \\
(10)\end{array}$ & $\begin{array}{l}23.75 \pm 1.71 \\
(10)\end{array}$ \\
\hline White \& Red & $\begin{array}{l}930.00 \pm 30.00 \\
\text { (2) }\end{array}$ & $\begin{array}{l}160.00 \pm 10.00 \\
\text { (2) }\end{array}$ & $\begin{array}{l}215.00 \pm 5.00 \\
(2)\end{array}$ & $\begin{array}{l}20.00 \\
(2)\end{array}$ \\
\hline Total & $\begin{array}{l}961.50 \pm 17.80 \\
(100)\end{array}$ & $\begin{array}{l}152.71 \pm 1.31 \\
(100)\end{array}$ & $\begin{array}{l}219.00 \pm 1.89 \\
(100)\end{array}$ & $\begin{array}{l}25.57 \pm 0.61 \\
(100)\end{array}$ \\
\hline Skin Color & NS & NS & NS & NS \\
\hline White & $\begin{array}{l}957.53 \pm 19.03 \\
(89)\end{array}$ & $\begin{array}{l}153.3 \pm 1.38 \\
(89)\end{array}$ & $\begin{array}{l}218.76 \pm 1.98 \\
(89)\end{array}$ & $\begin{array}{l}25.59 \pm 0.67 \\
(89)\end{array}$ \\
\hline Yellow & $\begin{array}{l}1020.00 \pm 65.60 \\
(8)\end{array}$ & $\begin{array}{l}148.12 \pm 4.42 \\
(8)\end{array}$ & $\begin{array}{l}226.25 \pm 7.05 \\
(8)\end{array}$ & $\begin{array}{l}23.75 \pm 1.83 \\
\text { (8) }\end{array}$ \\
\hline Not Definite & $\begin{array}{l}865.00 \pm 35.00 \\
\text { (2) }\end{array}$ & $\begin{array}{l}140.00 \\
(2)\end{array}$ & $\begin{array}{l}200.00 \pm 10.00 \\
(2)\end{array}$ & $\begin{array}{l}30.00 \\
(2)\end{array}$ \\
\hline Total & $\begin{array}{l}960.70 \pm 17.90 \\
(100)\end{array}$ & $\begin{array}{l}152.62 \pm \quad 1.30 \\
(100)\end{array}$ & $\begin{array}{ll}218.99 \pm & 1.90 \\
(100) & \end{array}$ & $\begin{array}{l}25.53 \pm 0.62 \\
(100)\end{array}$ \\
\hline
\end{tabular}

NS=Non Significant, Figure in the parentheses indicate the number of observation. 
Table 5.4: Effects of earlobe and eggshell color on morphometric traits

\begin{tabular}{|c|c|c|c|c|}
\hline $\begin{array}{l}\text { Phenotypic } \\
\text { Parameter }\end{array}$ & $\begin{array}{l}\text { Body Weight } \\
\text { (gm) }\end{array}$ & $\begin{array}{c}\text { Back Length } \\
\text { (mm) }\end{array}$ & $\begin{array}{c}\text { Body } \\
\text { Circumference } \\
(\mathbf{m m})\end{array}$ & $\begin{array}{c}\text { Pelvis } \\
\text { Width(mm) }\end{array}$ \\
\hline Earlobe Color & NS & NS & NS & NS \\
\hline White & $\begin{array}{l}981.56 \pm 29.12 \\
(32)\end{array}$ & $\begin{array}{l}152.03 \pm 2.24 \\
(32)\end{array}$ & $\begin{array}{l}221.56 \pm 3.60 \\
(32)\end{array}$ & $\begin{array}{l}25.85 \pm 0.90 \\
(32)\end{array}$ \\
\hline Red & $\begin{array}{l}968.12 \pm 40.23 \\
(16)\end{array}$ & $\begin{array}{l}149.69 \pm 3.55 \\
(16)\end{array}$ & $\begin{array}{l}226.25 \pm 4.73 \\
(16)\end{array}$ & $\begin{array}{l}23.12 \pm 1.50 \\
(16)\end{array}$ \\
\hline Red Brown & $\begin{array}{l}1050.00 \pm 170.00 \\
(2)\end{array}$ & $\begin{array}{l}165.00 \pm 5.00 \\
(2)\end{array}$ & $\begin{array}{l}220.00 \pm 10.00 \\
(2)\end{array}$ & $\begin{array}{l}40.00 \pm 5.00 \\
\text { (2) }\end{array}$ \\
\hline White \& Red & $\begin{array}{l}931.49 \pm 26.96 \\
(47)\end{array}$ & $\begin{array}{l}153.40 \pm 1.80 \\
(47)\end{array}$ & $\begin{array}{l}214.47 \pm 2.58 \\
(47)\end{array}$ & $\begin{array}{l}25.53 \pm 0.90 \\
(47)\end{array}$ \\
\hline Others & $\begin{array}{l}1123.30 \pm 144.02 \\
\text { (3) }\end{array}$ & $\begin{array}{l}156.67 \\
\pm 12.01\end{array}$ & $\begin{array}{l}230.00 \pm 5.78 \\
(3)\end{array}$ & $\begin{array}{l}26.67 \pm 3.33 \\
\text { (3) }\end{array}$ \\
\hline Total & $\begin{array}{l}961.50 \pm 17.80 \\
(100)\end{array}$ & $\begin{array}{l}152.70 \pm 1.29 \\
(100)\end{array}$ & $\begin{array}{l}219.20 \pm 1.89 \\
(100)\end{array}$ & $\begin{array}{l}25.57 \pm 0.61 \\
(100)\end{array}$ \\
\hline Eggshell Color & NS & NS & NS & NS \\
\hline White & $\begin{array}{l}1010.20 \pm 18.39 \\
(48)\end{array}$ & $\begin{array}{l}151.04 \pm 1.60 \\
(48)\end{array}$ & $\begin{array}{l}223.12 \pm 2.25 \\
(48)\end{array}$ & $\begin{array}{l}26.77 \pm 0.79 \\
(48)\end{array}$ \\
\hline Red & $\begin{array}{l}1050.00 \pm 270.00 \\
(2)\end{array}$ & $\begin{array}{l}165.00 \pm 5.00 \\
(2)\end{array}$ & $\begin{array}{l}220.00 \pm 10.00 \\
\text { (2) }\end{array}$ & $\begin{array}{l}40.00 \pm 5.00 \\
\text { (2) }\end{array}$ \\
\hline Red Brown & $\begin{array}{l}1012.50 \pm 41.22 \\
(20)\end{array}$ & $\begin{array}{l}157.00 \pm 2.41 \\
(20)\end{array}$ & $\begin{array}{l}224.00 \pm 3.28 \\
(20)\end{array}$ & $\begin{array}{l}25.00 \pm 1.36 \\
(20)\end{array}$ \\
\hline Others & $\begin{array}{l}892.08 \pm 34.48 \\
(24)\end{array}$ & $\begin{array}{l}150.40 \pm 3.21 \\
(24)\end{array}$ & $\begin{array}{l}214.58 \pm 4.34 \\
(24)\end{array}$ & $\begin{array}{l}23.85 \pm 1.06 \\
(24)\end{array}$ \\
\hline Not Definite & $\begin{array}{l}650.00 \pm 66.28 \\
(6)\end{array}$ & $\begin{array}{l}156.67 \pm 7.61 \\
(6)\end{array}$ & $\begin{array}{l}190.00 \pm 8.94 \\
(6)\end{array}$ & $\begin{array}{l}20.00 \pm 2.58 \\
\text { (6) }\end{array}$ \\
\hline Total & $\begin{array}{l}962.32 \pm 17.95 \\
(99)\end{array}$ & $\begin{array}{l}152.63 \pm 1.30 \\
(99)\end{array}$ & $\begin{array}{l}219.30 \pm 1.90 \\
(99)\end{array}$ & $\begin{array}{l}25.48 \pm .61 .00 \\
(99)\end{array}$ \\
\hline
\end{tabular}

NS=Non Significant, Figure in the parentheses indicate the number of observation. 

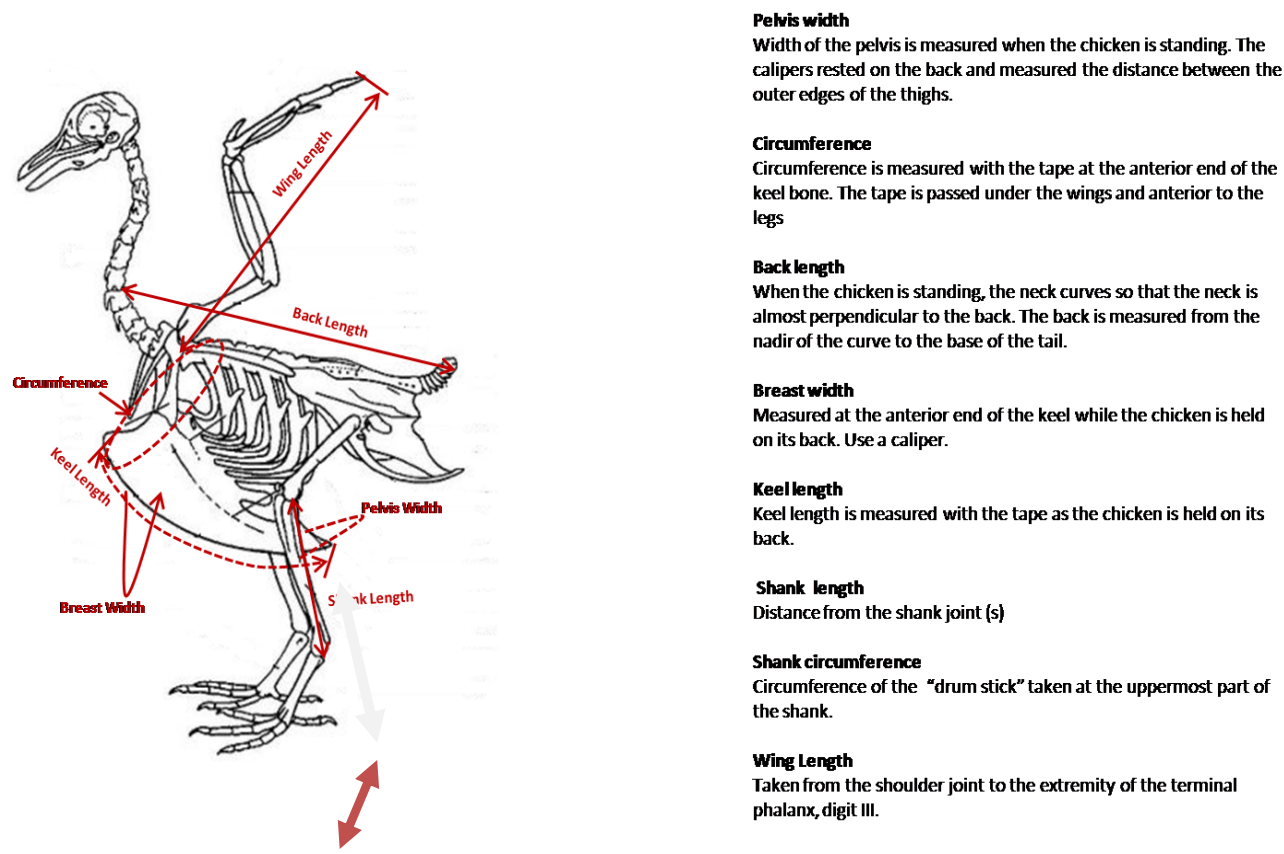

Figure 1: Linear measurements of a chicken showing Back Length, Circumference, Pelvis Width, Shank Length, Keel Length, Wing Length and Breast Width

Source: Blood sampling procedure and in-depth monitoring survey manual for indigenous chicken, goats and pigs of UNEP-GEF-ILRI FAnGR Asia Project on 2010 (BSPIMSM , 2010). 